\title{
Does Individual Anxiety Play a Mediating Role on the Impact of Psychological Expectation of Class Mobility on Entrepreneurial Choice?
}

\section{Junhui Han \\ Kemin Xiao \\ Xiaoqiong Zhao}

School of Economics and Management, Taiyuan University of Technology, Jinzhong, People's Republic of China
Correspondence: Junhui Han

Tel +86 I53 868I 9306

Email kjcyyk@126.com
Purpose: Under the dual backgrounds of "Chinese dream" and "Mass entrepreneurship and innovation", can psychological expectations influence entrepreneurial activities? There is little literature on this topic. In addition, although psychological expectation can reduce the negative emotions caused by uncertain events, the expectation itself can lead to the activation of related neural circuits and the generation of individual anxiety. According to Maslow's hierarchy of needs, this paper divides the entrepreneurship into the economic status type, the social status type and the self-development type, and attempts to study the psychological mechanism of the psychological expectation of class mobility influencing entrepreneurial choice by constructing the mediating effect model of individual anxiety.

Methods: Based on CGSS 2015 data, entrepreneurial choice was obtained through describing the working status. The individual anxiety in the questionnaire is "How often have you felt depressed or disheartened in the past four weeks?". Psychological expectation of class mobility was calculated by subtracting the current subjective class score from the subjective class score 10 years later. Classical mediating effect models were conducted by stata 15.0. Results: The psychological expectation of class mobility can promote entrepreneurial behavior. According to sub sample study, individual anxiety plays a partial mediating effect between the psychological expectation of class mobility and economic status type entrepreneurships. No mediating effect of individual anxiety occurs for social status type and selfdevelopment type entrepreneurships.

Conclusion: This study provides a psychological mechanism by which the expectation of class mobility affects entrepreneurial choice. The implications are as follows: we should firstly prevent excessive anxiety from triggering irrational entrepreneurship. Secondly, we should establish a fair social mobility mechanism to provide psychological incentives for entrepreneurial groups to flow upward through entrepreneurship. Thirdly, we undertake classification management of entrepreneurial groups and pay attention to social status type and self-development type entrepreneurial.

Keywords: entrepreneurship, psychological expectation of class mobility, anxiety, mediating effect

\section{Introduction}

The psychological expectation of class mobility is an individual's antecedent estimate of the direction and distance of class mobility in the future, or the individual's psychological preparation for his or her future class status. Under the guidance of the "Chinese dream", most people are confident and optimistic about upward mobility. ${ }^{1}$ On the other hand, since "Mass entrepreneurship and innovation" 
was put forward in 2014, entrepreneurship and innovation activities have attracted great attention from social circles. However, entrepreneurship is a high-risk process, which requires entrepreneurs not only to have economic resources and social network, but also to have selfefficacy and pressure resistance. ${ }^{2-4}$ In the practice of entrepreneurship, entrepreneurs who are confident about the future will face challenges bravely and believe that they can get expected resources and succeed. ${ }^{5}$ Then, from the perspective of social psychology, will expectation of class mobility promote entrepreneurial activities?

In addition, psychological theory believes that although psychological expectation can make individuals take precaution measures towards upcoming negative events and then weaken the negative emotional experiences elicited by these events, ${ }^{6}$ this expectation process itself has been shown to result in activations of emotion-related neural circuits and individual anxiety. ${ }^{7,8}$ At present, anxiety is becoming a common phenomenon in society. If the psychological expectation theory is applied to the relationship between social mobility and entrepreneurial activities, what role will individual anxiety play?

Based on the above Chinese background and psychological theories, this paper uses CGSS2015 data to explore the impact of psychological expectation of class mobility on entrepreneurial activities and the mediating effect of individual anxiety. The contributions of this paper are mainly reflected in the following aspects: Firstly, entrepreneurial behavior was studied from the perspective of social class mobility or social mentality. In the available entrepreneurial literature, psychological theories focus on the factors affecting individuals at the micro level; Sociology regards entrepreneurship as a social action and emphasizes the interaction between entrepreneurship and social transformation. ${ }^{9}$ It can be said that this paper expands the entrepreneurship literature from psychological theory to social psychology. Secondly, this paper divides the entrepreneurship into the type in pursuit of economic status, of social status and of self-development. It is generally believed that necessity and opportunity entrepreneurship are the main type of entrepreneurship. ${ }^{10}$ Based on Maslow's hierarchy of needs, this paper makes a further detailed study of entrepreneurial types. Thirdly, In the context of Chinese society, few literatures have studied the relationship between individual anxiety and entrepreneurial decision. ${ }^{11}$ In this paper, the psychological expectation of class mobility, individual anxiety and entrepreneurial choice are analyzed in a unified framework, which will further deepen the understanding of entrepreneurial activities.

\section{Literature Review and Research Hypothesis \\ Individual Anxiety and Entrepreneurial Choice}

Entrepreneurship is a highly charged and extremely risky activity. Emotional support and cooperation are needed in the entire decision-making process. ${ }^{12}$ However, the research on entrepreneurship from the perspective of emotion remains inchoate begun. ${ }^{13}$ Entrepreneurial passion has attracted considerable attention among entrepreneurial emotions. Passion can enhance the creativity of entrepreneurs and further affect their information processing and decision-making process. At the same time, passion can also influence team members, families and customers so as to obtain the corresponding resource supports and facilitate success. ${ }^{12-14}$ Moreover, the impact of emotions such as happiness, hope, interest, gratitude and pride on the cognitive activities of entrepreneurs has also attracted scholars' attention. ${ }^{15,16}$

Positive emotions can undeniably promote entrepreneurial behavior. However, with rapid economic development, the social gap between the rich and the poor is widening and impetuous emotion is prevalent. Anxiety is becoming an ordinary phenomenon in the society. ${ }^{17}$ As a psychological phenomenon, anxiety is a self-protective emotional response of individuals who face uncertainty and lack coping means. ${ }^{18}$ How do negative emotions such as anxiety affect individuals' entrepreneurial activities? Some scholars believe that anxiety is a psychological barrier to entrepreneurship. They emphasize the notion of the inhibitory effect of anxiety on entrepreneurship. ${ }^{19}$ Nevertheless, certain researchers suppose that anxiety may stimulate individuals to exert great efforts and encourage them to participate in more specific activities. ${ }^{20}$ If anxiety is divided into normal anxiety and neurotic anxiety, then the former may bring vitality to individuals. The underlying logic may be expressed as anxiety leads to stress, which in turn leads to effort. ${ }^{18}$ The possibility of individuals starting an undertaking will increase with the increase of anxiety about the future. ${ }^{11}$ However, heterogeneity occurs in entrepreneurial activities. For example, most literature categorize entrepreneurship into the necessity and opportunity entrepreneurship according to entrepreneurial motivation. ${ }^{10}$ In line with Maslow's Hierarchy 
of Needs, entrepreneurship is divided into the type in pursuit of economic status (the economic status type), of social status (the social status type) and of selfdevelopment (the self-development type) in this study. Given different entrepreneurial motivations, the same factor may pose different effects on different entrepreneurial types, and the same is true for individual anxiety. For example, according to the push and pull theories of entrepreneurship proposed by Amit et al, ${ }^{21}$ we believe that social status and self-development entrepreneurship are mostly driven by internal positive emotions such as happiness, expanding social circle and personal growth, while economic status entrepreneurship is driven by negative emotions such as anxiety and dissatisfaction with life. Consequently, the following hypothesis is proposed:

Hypothesis 1: Individual anxiety has different effects on economic status type, social status type and selfdevelopment type entrepreneurship.

Hypothesis 2: The higher the psychological expectation of class mobility is, the more entrepreneurial activities can be promoted.

\section{Class Mobility and Individual Anxiety}

Currently, China's overall class mobility rate is gradually rising. ${ }^{29}$ From an objective point of view, different forms of survival anxiety and development panic are distributed in various classes. ${ }^{25}$ Many individuals of the middle and lower classes lack social resources. Furthermore, the room for survival and development is relatively squeezed, so it is easier to have anxiety. Less anxiety arises in the powerful groups at the upper class. Moreover, the social public's subjective class identity shows an obvious downward tendency. The percentage of people who identify themselves as middle class is low and the counterpart for lower class identity is high. ${ }^{30}$ Does class identity at a lower level represent a kind of anxiety and helplessness? Studies have shown that a low comprehensive evaluation of their own economic and social status makes it easier to cause anxiety. ${ }^{31}$ Finally, both objective class status and subjective class identity (evaluation) have a negative relationship with individual anxiety.

Does psychological expectation of class mobility have an impact on individual anxiety? Many literatures in experimental psychology show that although psychological expectation can make individuals prepare psychologically for potential uncertain events and reduce the negative emotions caused by these events, this expectation process itself has been shown to lead to the activation of related neural circuits and the generation of anxiety experience. ${ }^{6-8}$ In the era of a knowledge economy, industrial transformation and upgrading are accelerating, while pressure and anxiety pervade the entire society. Individuals at the middle and lower class are most afraid of being eliminated by the market, thereby resulting in very strong survival anxiety and development panic. Starting their own business has become an important channel for upward mobility. ${ }^{32}$ They hope to realize climbing or leaping-over in the class through entrepreneurship. Nevertheless, their own economic conditions and the lack of social resources means that those individuals fantasize about upward mobility in the future from the subjective aspect, a feature which is an expression of self-confidence but is accompanied by anxiety. The goal they set for themselves is higher, and they may feel a greater degree of anxiety. Accordingly, the following research hypothesis is proposed:

Hypothesis 3: Psychological expectation of class mobility has a significantly positive impact on individual anxiety.

\section{Class Mobility and Entrepreneurial Choice}

Class mobility or social mobility refers to the objective change of individuals from one social status or social class to another. ${ }^{22}$ Social mobility may affect individual psychology and behavioral choices. For example, the separation theory holds that when social individuals separate from their original social class, this change will generate psychological pressure which will make individuals pay more attention to their personal interests and ignores the interests of others, thereby showing low social participation willingness. ${ }^{23}$ The research on well-being reveals that individuals upward mobility of can positively predict their wellbeing, and their downward mobility has a significantly negative impact on their well-being. ${ }^{24}$ Few studies explore the relationship between class status and entrepreneurial willingness. Significant variations also occur in individual entrepreneurial participation willingness among all classes. ${ }^{25}$

Objective class or social mobility aims to measure whether social individuals benefit under the existing institutional conditions. Subjective social mobility is a social individual's subjective experience of real life and reflects the individual's recognition and satisfaction with the obtained social class and existing living standard. This indicator has great impact on the individual's attitude and behaviour. ${ }^{26,27}$ At the subjective level, class mobility can be divided into 
two forms from the perspective of time dimension. The first one is class mobility perception according to the individual's own experience. This index reflects the individual's subjective evaluation of the change of social status in a certain period of the past. The second one is in line with the individual's estimation and speculation of class mobility in the future. This psychological activity is called the psychological expectation of class mobility. High psychological expectation of class mobility means the accumulation of capital and the enhancement of self-identity and will pose a positive impact on entrepreneurial activities. ${ }^{28}$ This notion coincides with the self-confidence of entrepreneurs as emphasized by entrepreneurial self-efficacy. Entrepreneurs are full of hope for the future, their high expectations of upward mobility can provide them with psychological motivation and make them to be more predictive of entrepreneurial decision-making. Thus, the following hypothesis is proposed:

In line with Maslow's Hierarchy of Needs, entrepreneurship was classified into three categories in this study. The psychological expectation of class mobility, individual anxiety and entrepreneurship were assumed to constitute the mediating effect model. In summary, the following theoretical model is proposed in this paper (Figure 1).

\section{Materials and Methods Data Source}

The data used in this paper are from the Chinese General Social Survey (CGSS). This database was conducted by the Survey Research Center of the Hong Kong University of Science and Technology in cooperation with the Department of Social Sciences, Renmin University of China. The database mainly focuses on theoretical and practical issues in the process of social change in China, especially information about residents' lifestyles and thinking patterns. Considering the availability of the variables, this paper uses the CGSS 2015 data which includes questions on individual anxiety, working status and expectation of class mobility. According to the respondents' answers, we can measure these variables. Following the purpose of the research, 3498 samples were retained by deleting missing values and outliers.

\section{Measures}

\section{Entrepreneurial Choice}

This variable is obtained through describing the work conditions in the questionnaire. Specifically, the respondents' current work conditions are divided into nine types: namely (1) as a boss (partner); (2) individual businesses; (3) employed by others (with a fixed employer); (4) labour worker/labour dispatch personnel; (5) odd job and jobwork (employee without fixed employer); (6) work/help in their own businesses/enterprises, with pay; (7) work/help in their own businesses/enterprises, without pay; (8) freelancer; and (9) others. In all samples, Options (1), (2) and (8) are regarded as entrepreneurial activities. Furthermore, entrepreneurship types are distinguished in the samples in Options (1), (2) and (8). The following problems are included in the questionnaire: "People want to get some benefits or returns from their work. Which one do you want most?" Options (1) high income; (2) long term security; (3) social prestige and respect; (4) greater authority; (5) satisfying personal interests; (6) promotion opportunities; (7) short working hours; (8) broadening personal social relations; (9) be able to serve the public and society; (10) giving full play to personal intelligence and having a sense of achievement; (11) more free time to use; and (12) others. Here, the entrepreneurs in Options (1), (2) and (6) are selected as the economic status type; in Options (3), (4), (8) and (9) are selected as the social

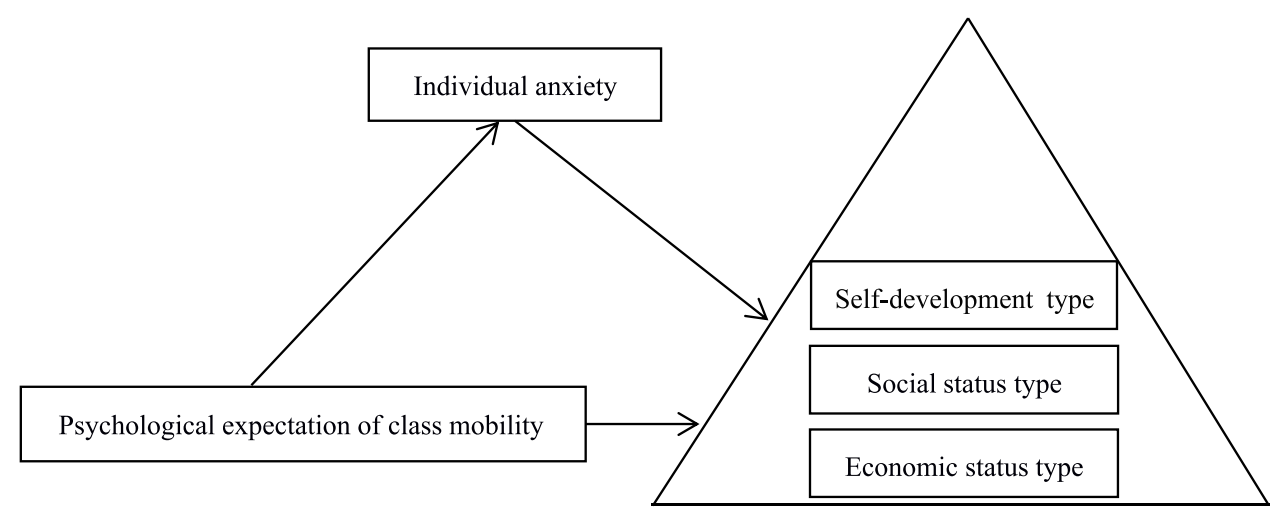

Figure I Theoretical model. 
status type; and in other options excluding Option (12) are classified as the self-development type. The descriptive statistical analysis in Table 1 reveals that nearly $23.1 \%$ of the respondents are entrepreneurs.

\section{Individual Anxiety}

The question related to anxiety emotion in the questionnaire is "How often have you felt depressed or disheartened in the past four weeks"? The options include (1) always, (2) frequently, (3) sometimes, (4) rarely and (5) never. According to the answer to this question, the degree of anxiety of the respondents is judged through numeric conversion. That is, always $=5$, frequently $=4$, sometimes $=3$, rarely $=2$ and never $=1$.

\section{Psychological Expectation of Class Mobility}

Psychological expectation of class mobility reflects the individual's subjective evaluation of the direction of class mobility in the future. The questionnaire involves related issues. For the part on class identity, the respondents are shown a 10-level ladder marked with 10 numbers (1 to 10) from the bottom to the top. The highest score (10 points) represents the top, and the lowest score 1 point represents the bottom. The respondents are asked to select a number to show their subjective class level. If the number is large, the evaluation of the class level they located is high. This question item asks "What level do you think you are at now?" and "What level do you think you will be in ten years later?" In this paper, the subjective class score 10 years later is used to subtract the current subjective class score to measure the psychological expectation of class mobility, an approach which is similar to that of Zhang et al. ${ }^{33}$

\section{Demographic Information}

The demographic Information in this paper are mainly at two levels: individual and family. The former include age,

Table I Variable Description and Descriptive Statistics

\begin{tabular}{|c|c|c|c|c|c|}
\hline Variables & $\begin{array}{l}\text { Average } \\
\text { Value }\end{array}$ & $\begin{array}{l}\text { Standard } \\
\text { Deviation }\end{array}$ & $\begin{array}{l}\text { Minimum } \\
\text { Value }\end{array}$ & $\begin{array}{l}\text { Maximum } \\
\text { Value }\end{array}$ & Description of Variable Settings \\
\hline $\begin{array}{l}\text { Entrepreneurial } \\
\text { choice }\end{array}$ & 0.231 & 0.422 & 0 & I & Entrepreneurship $=1$, no entrepreneurship $=0$ \\
\hline Individual anxiety & 1.979 & 0.853 & I & 5 & $\begin{array}{l}\text { Always }=5 \text {, frequently }=4 \text {, sometimes }=3 \text {, rarely }=2 \text { and never } \\
=1\end{array}$ \\
\hline $\begin{array}{l}\text { Psychological } \\
\text { expectation of class } \\
\text { mobility }\end{array}$ & 1.142 & 1.305 & -4 & 9 & $\begin{array}{l}\text { Subjective class score } 10 \text { years later minus current subjective } \\
\text { class score }\end{array}$ \\
\hline Age & 39.323 & 10.616 & 18 & 60 & The survey year 2015 minus the year of birth \\
\hline Education & 11.143 & 3.393 & I & 15 & $\begin{array}{l}\text { No formal education }=1 \text {, primary school }=6 \text {, junior middle } \\
\text { school }=9 \text {, senior high school }=12 \text {, and junior college and above } \\
=15\end{array}$ \\
\hline Marital cohabit & 0.803 & 0.398 & 0 & I & $\begin{array}{l}\text { Unmarried, separated but not divorced, divorced and widowed = } \\
0 \text { and other cohabitation conditions }=1\end{array}$ \\
\hline $\begin{array}{l}\text { Parental } \\
\text { entrepreneurial } \\
\text { experience }\end{array}$ & 0.074 & 0.262 & 0 & I & $\begin{array}{l}\text { Do your parents have entrepreneurial experience? Yes }=I \text { and } \\
\text { No }=0\end{array}$ \\
\hline Gender & 0.552 & 0.497 & 0 & I & Male $=I$ and female $=0$ \\
\hline Political status & 0.18 & 0.384 & 0 & I & $\begin{array}{l}\text { Common people }=0 \text { and members of the Communist Youth } \\
\text { League, Democratic parties and Communist Party }=1\end{array}$ \\
\hline Family income & 2.784 & 0.695 & I & 5 & $\begin{array}{l}\text { Far lower than average }=1, \text { lower than average }=2 \text {, average }=3 \text {, } \\
\text { higher than average }=4 \text { and far higher than average }=5\end{array}$ \\
\hline $\begin{array}{l}\text { Household } \\
\text { registration }\end{array}$ & 0.445 & 0.497 & 0 & I & Rural $=I$ and urban $=0$ \\
\hline
\end{tabular}


education, health status, gender, political status, marital cohabit. The latter include household registration, family income and parental entrepreneurial experience. Considering their independent decision-making ability and labor participation, the respondents aged 18-60 are selected. In addition, individual entrepreneurship should be supported by family members, especially spouses. Cohabitation is the most obvious way to get economic and emotional support. For this reason, marital and cohabitation status is observed according to whether respondents are living together or not, a feature which differs from most of previous literature. Family income and parental entrepreneurial experience may also have an impact on individual entrepreneurial choice. Urban and rural household registration is likewise controlled. The descriptive statistics of all variables are shown in Table 1.

\section{Statistical Model Analyses}

This paper firstly investigates the impact of psychological expectation of class mobility on entrepreneurial choice and then explores whether that expectation has an impact on entrepreneurial behaviour through the mediating effect of individual anxiety. Based on entrepreneurial studies and the classical mediating effect model, Equations (1)-(3) are established. For convenience, the control variables are omitted here.

$$
\begin{gathered}
P\left(\text { Entre }_{i}=1\right)=\phi\left(\text { cExpectmo }_{i}+\varepsilon_{i 1}\right) \\
\text { Anxiety } \left._{i}=\text { aExpectmo }_{i}+\varepsilon_{i 2}\right) \\
P\left(\text { Entre }_{i}=1\right)=\phi\left(c^{\prime} \text { Expectmo }_{i}+\text { bAnxiety }_{i}+\varepsilon_{i 3}\right)
\end{gathered}
$$

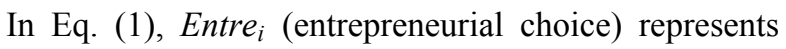
whether a respondent started a business or not (1 means entrepreneurship and 0 means no entrepreneurship). c refers to the total effect of the independent variable Expectmob $_{i}$ (psychological expectation of class mobility) on the dependent variable Entre E $_{i}$. In Eq. (2), a refers to the effect of independent variable Expectmo $_{i}$ on mediating variable Anxiety $_{i}$ (individual anxiety). In Eq. (3), b refers to the effect of mediating variable Anxiety $_{i}$ on dependent variable Entre $_{i}$ after controlling the independent variable $E_{\text {Expectmo }}$.c' refers to the direct effect of the independent variable Expectmo $_{i}$ on the dependent variable Entre E $_{i}$. For testing the mediating effect, the stepwise test regression coefficient method is simple and easy to do. However, its statistical examination is limited, so the Sobel test method is employed in this study. In addition, an endogeneity problem may be produced in Model (1) because of the reciprocal cause-effects relationship. Thus, the IV Probit model is used to deal with the problem in this study. Further details are provided below.

\section{Results}

\section{Impact of Psychological Expectation of Class Mobility on Entrepreneurial Choice} Table 2 shows the impact of psychological expectation of class mobility on entrepreneurial choice by full samples according to the above regression Eq. (1). The regression coefficient of psychological expectation of class mobility is 0.0871 , and this value is significant at the level of $1 \%$.

\begin{tabular}{|c|c|}
\hline Variables & $\begin{array}{c}\text { Entrepreneurial } \\
\text { Choice }\end{array}$ \\
\hline $\begin{array}{l}\text { Psychological expectation of class } \\
\text { mobility }\end{array}$ & $\begin{array}{l}0.087 I^{* * *} \\
(0.0196)\end{array}$ \\
\hline Age & $\begin{array}{c}0.0790 * * * \\
(0.0197)\end{array}$ \\
\hline Age square & $\begin{array}{c}-0.000962 * * * \\
(0.00024 I)\end{array}$ \\
\hline Education & $\begin{array}{l}0.0920 * * * \\
(0.0338)\end{array}$ \\
\hline Education square & $\begin{array}{c}-0.00794^{* * * *} \\
(0.00169)\end{array}$ \\
\hline Marital cohabit & $\begin{array}{l}0.295 * * * \\
(0.0769)\end{array}$ \\
\hline Gender & $\begin{array}{l}0.0869 * \\
(0.0501)\end{array}$ \\
\hline Political status & $\begin{array}{c}-0.298 * * * \\
(0.0789)\end{array}$ \\
\hline Parental entrepreneurial experience & $\begin{array}{l}0.389 * * * \\
(0.0937)\end{array}$ \\
\hline Family income & $\begin{array}{l}0.233 * * * \\
(0.0363)\end{array}$ \\
\hline Household registration & $\begin{array}{l}0.185 * * * \\
(0.0555)\end{array}$ \\
\hline Observed value & 3498 \\
\hline Pseudo $\mathrm{R}^{2}$ & 0.0841 \\
\hline
\end{tabular}

Table 2 The Impact of Psychological Expectation of Class Mobility on Entrepreneurial Choice

Notes: (I) Standard errors are in brackets; (2) ***, *Indicate significance level at the $1 \%$ and $10 \%$ levels, respectively. 
Thus, psychological expectation of class mobility has a significantly positive effect on the entrepreneurial choice of individuals. According to the marginal effect, the probability of an individual choosing entrepreneurship will be increased by $2.508 \%$ with the increase of psychological expectation of class mobility by a unit value. Hypothesis 2 is thus validated.

Meanwhile, age has a positive impact on the entrepreneurial choice of individuals, but the regression coefficient of age squared term is negative and is significant at the level of $1 \%$. Therefore, an inverse U-shaped relationship exists between age and entrepreneurial choice. That is, with the increase of age, the probability of choosing entrepreneurship increases. After an inflection point, however, the probability of choosing entrepreneurship decreases. The regression coefficient of educational is similar to age. The regression coefficient of marital cohabit is 0.295 and is significant at the level of $1 \%$. This outcome means that couples or lovers living together can increase the probability of entrepreneurship. After all, cohabitation can generate emotional and economic support, thereby helping entrepreneurial activities. According to the marginal effects, the probability of entrepreneurship in respondents who are members of the Communist Youth League, Democratic Parties and Communist Party will be reduced by $7.899 \%$. This result is quite consistent with the reality of Chinese society. Party members and other groups are more inclined to work in the public sector. The probability for them to start businesses is very low. Note that Table 2 shows that parental entrepreneurial experience has a great impact on entrepreneurial choice. The regression coefficient is 0.389 . This means that entrepreneurial behaviour has significant intergenerational transmission. That is, parents may affect their children's entrepreneurial behaviors through social network, entrepreneurial experience and financial support. Family income also has a significantly positive effect on the entrepreneurial choice. Compared with individuals with urban household registration, those with rural household registration prefer to engage in entrepreneurship.

\section{Endogeneity Test}

Taking the logarithm of the number of house properties in the CGSS 2015 data as the instrumental variable, Table 3 reports the endogeneity test results using the IVProbit model. This study assumes that only one endogenous variable is present, so the maximum likelihood estimation method (MLE) is adopted for the estimation. Table 3 shows that the Wald test value of the exogenous hypothesis on the psychological expectation of class mobility is 18.89 , and its $\mathrm{p}$ value is 0 . Therefore, the
Table 3 Estimation Results of the IV Probit Model

\begin{tabular}{|c|c|c|}
\hline Variables & $\begin{array}{c}\text { Dependent } \\
\text { Variables: } \\
\text { Entrepreneurial } \\
\text { Choice }\end{array}$ & $\begin{array}{c}\text { Dependent Variables: } \\
\text { Psychological } \\
\text { Expectation of Class } \\
\text { Mobility }\end{array}$ \\
\hline $\begin{array}{l}\text { Psychological } \\
\text { expectation of } \\
\text { class mobility }\end{array}$ & $\begin{array}{l}0.78 I^{* * *} \\
(0.0430)\end{array}$ & \\
\hline $\begin{array}{l}\text { Number of } \\
\text { house } \\
\text { properties }\end{array}$ & & $\begin{array}{l}0.202 * * * \\
(0.0647)\end{array}$ \\
\hline $\begin{array}{l}\text { Controlled } \\
\text { variable }\end{array}$ & Controlled & Controlled \\
\hline Sample size & 3166 & 3166 \\
\hline chi2(I) & \multicolumn{2}{|c|}{18.89} \\
\hline$P$ & \multicolumn{2}{|c|}{0.0000} \\
\hline
\end{tabular}

Notes: (1) Standard errors are in brackets; (2) ***Indicate significance level at the I\% levels.

psychological expectation of class mobility is an endogenous independent variable at the level of $1 \%$. Table 2 indicates that the impact of the psychological expectation of class mobility on entrepreneurial choice is only 0.0871 and is significant at the level of 0.01 . The IVProbit estimation result in Table 3 shows that the regression coefficient of psychological expectation of class mobility is 0.781 and is significant at the level of 0.01. Therefore, the positive impact of the psychological expectation of class mobility on entrepreneurial choice will be underestimated if only the Probit model is used for the estimation to ignore endogenous problems. The results in Table 3 also reveal that the number of house properties as an instrumental variable has a high explanatory power on the endogenous independent variable of the psychological expectation of class mobility.

\section{Heterogeneity and Test of the Mediating Effect of Individual Anxiety}

To further verify the heterogeneity of the entrepreneurial groups and analyze the mediating effect of individual anxiety at the same time, the full sample is divided into three subsamples. Subsample 1 consists of non-entrepreneurial and entrepreneurial individuals in pursuit of economic status. Subsample 2 consists of non-entrepreneurial and entrepreneurial individuals in pursuit of social status. Subsample 3 consists of non-entrepreneurial and entrepreneurial individuals in 
pursuit of self-development. To save space, the regression results of controlled variables are omitted here, and only the regression coefficients of the psychological expectation of class mobility and mediating variable individual anxiety are reported, as shown in Table 4 for details.
The result of Subsample 1 in model (1) indicates that the regression coefficient of the psychological expectation of class mobility is 0.0167 for economic status type entrepreneurship and is significant at the level of $1 \%$. Furthermore, the coefficient of the psychological expectation of class mobility in the

Table 4 Entrepreneurial Type Selection Based on Subsamples and Mediating Effect Test

\begin{tabular}{|c|c|c|c|}
\hline \multicolumn{4}{|c|}{ Test Results of Sample I } \\
\hline & Model (I) & Model (2) & Model (3) \\
\hline Main Variables & $\begin{array}{c}\text { Dependent Variable: Economic } \\
\text { Status Type }\end{array}$ & $\begin{array}{l}\text { Dependent Variable: Individual } \\
\text { Anxiety }\end{array}$ & $\begin{array}{c}\text { Dependent Variable: Economic } \\
\text { Status Type }\end{array}$ \\
\hline Individual anxiety & & & $\begin{array}{l}0.0353^{* * *} \\
(0.0077)\end{array}$ \\
\hline $\begin{array}{l}\text { Psychological expectation of class } \\
\text { mobility }\end{array}$ & $\begin{array}{l}0.0167 * * * \\
(0.0053)\end{array}$ & $\begin{array}{l}0.0233^{* *} \\
(0.0119)\end{array}$ & $\begin{array}{l}0.0159 * * * \\
(0.0053)\end{array}$ \\
\hline Other variables & Controlled & Controlled & Controlled \\
\hline Adj- $R^{2}$ & 0.0854 & 0.0331 & 0.0909 \\
\hline Sample size & \multicolumn{3}{|c|}{3310} \\
\hline \multicolumn{4}{|c|}{ Test Result of Sample 2} \\
\hline & Model (I) & Model (2) & Model (3) \\
\hline Main Variables & $\begin{array}{c}\text { Dependent Variable: Social Status } \\
\text { Type }\end{array}$ & $\begin{array}{l}\text { Dependent Variable: Individual } \\
\text { Anxiety }\end{array}$ & $\begin{array}{c}\text { Dependent Variable: Social Status } \\
\text { Type }\end{array}$ \\
\hline Individual anxiety & & & $\begin{array}{c}0.0031 \\
(0.0038)\end{array}$ \\
\hline $\begin{array}{l}\text { Psychological expectation of class } \\
\text { mobility }\end{array}$ & $\begin{array}{l}0.0064 * * \\
(0.0025)\end{array}$ & $\begin{array}{l}0.0249 * \\
(0.0127)\end{array}$ & $\begin{array}{l}0.0063^{* *} \\
(0.0025)\end{array}$ \\
\hline Other variables & Controlled & Controlled & Controlled \\
\hline Adj- $R^{2}$ & 0.0092 & 0.0245 & 0.0091 \\
\hline Sample size & \multicolumn{3}{|c|}{2765} \\
\hline \multicolumn{4}{|c|}{ Test Result of Sample 3} \\
\hline & Model (I) & Model (2) & Model (3) \\
\hline Main Variables & $\begin{array}{l}\text { Dependent Variable: Self- } \\
\text { development Type }\end{array}$ & $\begin{array}{l}\text { Dependent Variable: Individual } \\
\text { Anxiety }\end{array}$ & $\begin{array}{l}\text { Dependent Variable: Self- } \\
\text { development Type }\end{array}$ \\
\hline Individual anxiety & & & $\begin{array}{c}0.0067 \\
(0.0044)\end{array}$ \\
\hline $\begin{array}{l}\text { Psychological expectation of class } \\
\text { mobility }\end{array}$ & $\begin{array}{l}0.0099 * * * \\
(0.0029)\end{array}$ & $\begin{array}{l}0.0267 * * \\
(0.0126)\end{array}$ & $\begin{array}{l}0.0097 * * * \\
(0.0029)\end{array}$ \\
\hline Other variables & Controlled & Controlled & Controlled \\
\hline Adj- $R^{2}$ & 0.0144 & 0.0249 & 0.0149 \\
\hline Sample size & & 2795 & \\
\hline
\end{tabular}

Notes: (I) Standard errors are in brackets; (2) ***, **, *Indicate significance level at the $1 \%, 5 \%$ and $10 \%$ levels, respectively. 
model (2) of Subsample 1 on individual anxiety is 0.0233 and is significant at the level of 5\%. In model (3) of Subsample 1, the coefficients of both are significant at the level of $1 \%$. Therefore, individual anxiety plays a partial mediating effect between the psychological expectation of class mobility and economic status type entrepreneurship. Meanwhile, the regression coefficients of Subsample 2 in model (1) and (2) are also significant at the levels of 0.05 and 0.1 . However, when the psychological expectation of class mobility and individual anxiety are simultaneously included in the model (3) of Subsample 2, the regression coefficient of individual anxiety is not significant. The regression result of Subsample 3 is similar to that of Subsample 2. On the whole and from model (2) in the three subsamples, the psychological expectation of class mobility has a significantly positive impact on individual anxiety. Hypothesis 3 is thus validated.

The Sobel test method is applied to check the mediating effects of the three subsamples. For the Sobel test statistics of Subsample 1, the $\mathrm{Z}$ value is 1.798 ( $\mathrm{p}=$ 0.0721 ), thereby indicating that the mediating effect is significant at the level of $10 \%$. Thus, individual anxiety plays a significant mediating effect between the psychological expectation of class mobility and economic status type entrepreneurship. Subsamples 2 and 3 failed the Sobel test. That is, individual anxiety has no mediating effect between the psychological expectation of class mobility and social status type and self-development entrepreneurship. Therefore, Hypothesis 1 is validated.

\section{Discussion}

\section{Effect of Psychological Expectation of Class Mobility on Entrepreneurial Choice}

For the full sample, the probability of an individual choosing entrepreneurship will be increased by $2.508 \%$ with the increase of the psychological expectation of class mobility by a unit value. This outcome is significant at the level of $1 \%$. Thus, the psychological expectation of class mobility has a significantly positive effect on the entrepreneurial choice of individuals, which is similar with previous studies. For example, Han et al found that the net value of the current subjective class score minus the subjective class score ten years ago can promote entrepreneurship. ${ }^{28}$ The present study found that the difference between the subjective class score 10 years later and the current subjective class score has a positive effect on entrepreneurial activities. From the time dimension, the two conclusions are consistent.
Since its reform and opening up, China's social structure has gradually changed from a Pyramid to Olive type. Social mobility not only means the transformation of status and identity, ${ }^{34}$ but also affects people's willingness to participate in society. According to the acculturation thesis, upward mobility makes people feel proud of themselves and thus view society positively, which in turn shows a strong desire to participate in society. Conversely, downward mobility can be frustrating, which leads to less attention for society. ${ }^{23}$ Especially in the context of the "Chinese dream", most people are full of confidence in the future. Entrepreneurship may become an important way for many people to participate in social interaction and pursue their life dreams.

In addition, previous studies found that entrepreneurial self-efficacy was an important factor affecting entrepreneurship, ${ }^{5,35}$ If the psychological expectation of class mobility is regarded as an important dimension of self-efficacy, it can be said that the present study verifies the theory of selfefficacy from the perspective of social psychology.

\section{Probit Model}

With China's reform and opening up and the development of market economy, self-employment has become the main channel for upward mobility. In fact, high expectation of class mobility can promote entrepreneurship; but the successful entrepreneurial process may also boost an entrepreneur's confidence in upward mobility in turn. Another study illustrated that self-employment has significant influence on the anticipation of peasants' social mobility. ${ }^{36}$ Therefore, the present study may face an endogeneity problem caused by reciprocal causeeffects relationship. According to the CGSS 2015 data and relevant literature, we use the number of houses as an instrumental variable. Firstly, the number of residential properties is closely related to class identity, ${ }^{28}$ and is an important indicator of personal social status. In recent years and accompanied by high house prices, the importance of house properties has gradually become prominent and has become an important factor affecting class identity. ${ }^{37}$ Secondly, the Central Bank of China reports that urban housing ownership rate in China has reached $96 \%$, ranking first among the major countries in the world. Whether individuals start businesses or are employed by companies, house property is a necessity. House property also has little to do with entrepreneurial decision-making. ${ }^{28}$

Then, the IVProbit model is used for the endogeneity test. The Wald test rejects the null hypothesis that the psychological expectation of class mobility is an 
exogenous variable. The number of house properties as an instrumental variable has a strong explanatory power on the psychological expectation of class mobility. The positive impact of the psychological expectation of class mobility on entrepreneurial choice will be underestimated if only the Probit model is employed to make the estimation. It can be said that IVProbit model further proves that the psychological expectation of class mobility has a significant positive impact on entrepreneurial choice.

\section{Mediating Effect of Individual Anxiety}

It is not complete to treat entrepreneurial behavior from the perspective of pure economic rationality. ${ }^{38}$ In addition to physiological needs, entrepreneurial motivation is also closely related to psychological factors such as interest and happiness. ${ }^{39}$ Therefore, according to Maslow's hierarchy of needs, this paper divides the entrepreneurship into three types: pursuing economic status, social status and selfdevelopment. Accordingly, three mediation models of individual anxiety are established. The estimation results of three subsamples show that the psychological expectation of class mobility has a significantly positive impact on the three types of entrepreneurial choice. This means that the mediation effect model can be used for further exploration. ${ }^{40}$

In the three mediating models, the psychological expectation of class mobility have significant positive effect on individual anxiety. Numerous literature in experimental psychology shows that, in the psychological preparation stage, this anticipation process will lead to the attentional alertness effect and the activation of related neural circuits, even though uncertain events have not yet appeared. ${ }^{8,41,42}$ This process can result in subjective anxiety ${ }^{8,43}$ The conclusion of this paper is highly consistent with the above research literature This shows that the extension of the expectation theory in experimental psychology to real social scenes still has a strong explanatory power.

Furthermore, mediating effect models results showed that the increase of individual anxiety will stimulate or promote entrepreneurial activities to a certain extent. However, the mediating effect of individual anxiety exists only between the psychological expectation of class mobility and economic status type entrepreneurship. After all, acquiring wealth through starting a business is still the main purpose and motivation of most entrepreneurs. ${ }^{44}$ According to prospect theory, people are not willing to take risks when they are facing profits, but when they are facing losses, in order to reverse their disadvantages, they actively take risks and become adventurers. ${ }^{45}$ Based on prospect theory. A similar study conducted that the possibility of starting a business increases with an individual's anxiety level. ${ }^{11}$ The present study also proved this theory.

For entrepreneurs who pursue social status and selfdevelopment, why is there no mediating effect of individual anxiety? The reason for this conclusion may be related to the mentality of entrepreneurs. Entrepreneurs in pursuit of social status and self-development mostly consider internal needs, such as personal interests, social services and other factors as the primary entrepreneurial motivation, rather than the pursuit of economic income. In recent years, there has been a growing number of happiness-seeking entrepreneurs in China. ${ }^{44}$ For these entrepreneurs, entrepreneurship is a worthy pursuit of life style and intrinsic life value. Therefore, the increase of anxiety cannot change internal high-level needs and also cannot stimulate or promote entrepreneurial behaviour.

\section{Limitations}

The study elucidated the psychological mechanism between the psychological expectation of class mobility and entrepreneurial choice by introducing individual anxiety. However, there were some limitation that should be addressed. First, the variables in the study are only represented by one item in the questionnaire, which will reduce the credibility of the data. In order to improve the reliability and validity of data, future research should try to use scale study. Secondly, the samples were all from CGSS 2015 Date. Future studies should expand the time span and increase the sample sizes. In other words, it is necessary to use longitudinal data to further test the robustness of the conclusion. Thirdly, we should strengthen the research on young entrepreneurial groups. With the transformation of economic and social development, youth groups are not only facing greater survival anxiety, but also the main force of entrepreneurial activities. More valuable conclusions may be found through the study of the entrepreneurial behavior of youth groups.

\section{Conclusion}

The present study deepens the understanding of the relationship between social mentality, Individual anxiety and entrepreneurial activity in Chinese context. The psychological expectation of class mobility significantly and positively promotes entrepreneurial behavior. Using the number of residential properties as the instrumental variable, the estimation result is still robust. At the same time, the psychological expectation of class mobility has different effects on three types of entrepreneurial activities. In other words, there is heterogeneity. The 
psychological expectation of class mobility, individual anxiety and economic status type entrepreneurship can construct a significant mediating effect model. For social status type and self-development type entrepreneurships, the mediating effect of individual anxiety does not exist. The paper has an important instruction to entrepreneurship practice: Firstly, excessive anxiety must be prevented from triggering irrational entrepreneurship. Moderate anxiety can enhance individual entrepreneurial intention, but excessive anxiety will also cause entrepreneurial impulse or irrational entrepreneurship and will generate economic losses to individuals and families. This is extremely important for entrepreneurial individuals in pursuit of economic status. Secondly, a reasonable and fair social mobility mechanism must be established to relieve subjective mobility anxiety. We must gradually get rid of and break intergenerational inheritance and establish the mobility mechanism dominated by ability and other achieved factors. At the same time, the government should strengthen public services to relieve worries regarding the Individual upward mobility. Thirdly, we must pay attention to entrepreneurial groups in pursuit of social status and self-development. With the transformation and rapid development of the economic society, more and more individuals or young people begin to pursue self-worth. Social status type and self-development type entrepreneurship will become a life attitude and style. Therefore, we should pay greater attention to this type of entrepreneurial group and formulate relevant policies to help them succeed in entrepreneurship.

\section{Ethics Approval and Consent to Participate}

The study was conducted according to the guidelines of the Declaration of Helsinki, and approved by Biomedical Ethical Committee of Taiyuan University of Technology (Protocol Number: TYUT202108011).

\section{Funding}

This study was funded by The National Social Science Fund of China "Research on the formation mechanism and promotion strategy of relative poor population's sense of gain from the perspective of social mobility", grant number 20BSH128.

\section{Disclosure}

The authors declare no conflicts of interest.

\section{References}

1. Du HF, Liang Y, Chi P, King RB. Chinese perceive upward social mobility: how future mobility is influenced, but not limited by past mobility. Int J Psychol. 2021;56(5):1-10. doi:10.1002/ijop.12771

2. Chen CC, Greene PG, Crick A. Does entrepreneurial self-efficacy distinguish entrepreneurs from managers? J Bus Ventur. 1998;13 (4):295-316. doi:10.1016/S0883-9026(97)00029-3

3. Baum JR, Locke EA. The relationship of entrepreneurial traits, skill, and motivation to subsequent venture growth. $J$ Appl Psychol. 2004;89(4):587-598. doi:10.1037/0021-9010.89.4.587

4. Chen C. A research on entrepreneur's psychological capital and new venture performance: a moderating mediation model. Sci Res Manag. 2015;36(10):85-93. doi:10.19571/j.cnki.1000-2995.2015.10.011

5. Zhong WD, Huang ZX. Empirical research on the relationship of tie strength, self-efficacy and entrepreneurs performance. Forum Sci Technol China. 2012;(1):131-137. doi:10.13580/j.cnki.fstc.2012.01.008

6. Golub SA, Gilbert DT, Wilson TD. Anticipating one's troubles: the costs and benefits of negative expectations. Emotion. 2009;9 (2):277-281. doi:10.1037/a0014716

7. Acheson DT, Stein MB, Paulus MP, et al. Effects of anxiolytic treatment on potentiated startle during aversive image anticipation. Hum Psychopharmacol. 2012;27(4):419-427. doi:10.1002/hup.2243

8. Yang JM, Zhang S, Yuan JJ, Liu GY. The interactive regulation of negative emotions by anticipation and cognitive strategies. Adv Psychol Sci. 2015;23(8):1312-1323. doi:10.3724/SP.J.1042.2015.01312

9. Hu JG, Yang GH. Modern Chinese entrepreneurship study from sociological perspective. J GuiZhou Normal Univ. 2006;(2):58-62. doi:10.3969/j.issn.1001-733X.2006.02.012

10. Reynolds P, Bosma N, Autio E, et al. Global entrepreneurship monitor: data collection design and implementation 1998-2003. Small Bus Econ. 2005;24(3):205-231. doi:10.1007/s11187-005-1980-1

11. Weng J, Chen BY, Zhou BY, Wang J. Does anxiety of the future affect entrepreneurship? Zhejiang Acad J. 2018;(06):81-93. doi:10.16235/j.cnki.33-1005/c.2018.06.011

12. Baron RA. The role of affect in the entrepreneurial process. Acad Manag Rev. 2008;33(2):328-340. doi:10.2307/20159400

13. Zhang J, Zhang Y. Entrepreneurial passion: entrepreneurship research review from the emotional view. Sci Technol Prog Policy. 2017;34 (2):153-160. doi:10.6049/kjjbydc.2016040662

14. Cardon MS, Wincent J, Singh J, Drnovsek M. The nature and experience of entrepreneurial passion. Acad Manag Rev. 2009;34 (3):511-532. doi:10.5465/AMR.2009.40633190

15. Fredrickson BL. The value of positive emotions: the emerging science of positive psychology is coming to understand why it's good to feel good. Am Sci. 2003;91(4):330-335. doi:10.1511/ 2003.4.330

16. Zhou XH, Jiang F, Chen Y. The positive affect's theory of entrepreneurial cognition. China Industr Econ. 2014;(08):135-147. doi:10.19581/j.cnki.ciejournal.2014.08.011

17. Shi C, Zhao ZH. China has entered a period of "national anxiety"? Social injustice exacerbates anxiety; 2021. Available from: http:// news.cntv.cn/china/20111021/101911_1.shtml. Accessed December 17, 2021.

18. Tashiro N. Anxiety and Psychological Conflict. Chinese Version. Beijing: People's Medical Publishing Press; 2008.

19. Arenius P, Minniti M. Perceptual variables and nascent entrepreneurship. Small Bus Econ. 2005;24(3):233-247. doi:10.1007/s11187-005-1984-x

20. Elliot AJ, Church MA. A hierarchical model of approach and avoidance achievement motivation. J Pers Soc Psychol. 1997;72 (1):218-232. doi:10.1037/0022-3514.72.1.218

21. Amit R, Muller E. "Push" and "pull" entrepreneurship. J Small Bus Entrepreneur. 1995;12(4):64-80. doi:10.1080/08276331.1995.10600505 
22. Lu XY. The Divisions and changes of the contemporary Chinese social classes. Jiangsu Soc Sci. 2003;(04):1-9. doi:10.3969/j. issn.1003-8671.2003.04.001

23. Daenekindt S. The experience of social mobility: social Isolation, utilitarian individualism, and social disorientation. Soc Indic Res. 2017;133(1):15-30. doi:10.1007/s11205-016-1369-3

24. Chan TW. Social mobility and the well-being of individuals. $\mathrm{Br}$ J Sociol. 2018;69(1):183-206. doi:10.1111/1468-4446.12285

25. Wei JF. Class differentiation, intergenerational division of labor, and the new generation of migrant workers' willingness to participate in entrepreneurship. Macroeconomics. 2017;(06):132-146. doi:10.16304/j.cnki.113952/f.2017.06.015

26. Merkl P. Social Mobility and political attitudes: comparative perspectives. Am Polit Sci Rev. 1993;87(3):806-807. doi:10.2307/ 2938795

27. Sheng ZM. Social mobility and political trust: an empirical study based on CGSS 2006. Society. 2013;33(04):35-59. doi:10.15992/j. cnki.31-1123/c.2013.04.006

28. Han XD, Yang HL, Pu MZ, Zheng FT. Who are starting up businesses? Individual identification and entrepreneurial choices - an empirical analysis based on data of CGSS from 2010 to 2015. Finance Econ. 2019;(01):100-111.

29. Li LL, Zhu B. Changes in the pattern of intergenerational mobility in contemporary China. Soc Sci China. 2015;5(05):40-58.

30. Gu H. Study of class solidification from the perspective of social mobility: an analysis of the changes of social class mobility in China since the reform and opening up. Soc Sci Guangdong. 2015; (05):202-213. doi:10.3969/j.issn.1000-114X.2015.05.024

31. Hua HQ, Weng DJ. Social status, life experiences and anxiety. Society. 2013;33(1):136-160. doi:10.15992/j.cnki.31-1123/c.2013.01.008

32. Nee V. A theory of market transition: from redistribution to markets in state socialism. Am Sociol Rev. 1989;54(5):663-681. doi:10.2307/ 2117747

33. Zhang LN. Socioeconomic status, subjective mobile perception and the reproductive willingness of women of childbearing age: based on empirical research data of CGSS2013. J Xihua Univ. 2018;37 (3):40-48. doi:10.19642/j.issn.1672-8505.2018.03.006

34. Pang Q. Model analysis of mobility from the perspective of social justice. J Hebei Univ Eng. 2016;33(02):54-57. doi:10.3969/j. issn.1673-9477.2016.02.019
35. Sun HX, Guo SF, Chen HY. Entrepreneurial self-efficacy, entrepreneurial resources and farmers' entrepreneurial motivations. Stud Sci Sci. 2013;31 (12):1879-1888. doi:10.3969/j.issn.1003-2053.2013.12.017

36. Xie QS. The effect of self-employment on anticipation of peasants' social mobility. J South China Agric Univ. 2019;18(3):92-106. doi:10.7671/j.issn.1672-0202.2019.03.009

37. Zhang WH, Liu L. Research on housing and class identity. Jianghai Acad J. 2013;(4):91-100. doi:10.3969/j.issn.1000-856X.2013.04.015

38. Ryan RM, Deci EL. Self-determination theory and the facilitation of intrinsic motivation, social development, and well-being. $\mathrm{Am}$ Psychol. 2000;55(1):68-78. doi:10.1037/0003-066x.55.1.68

39. Mcmahon RGP, Stanger AMJ. The small enterprise financial objective function: an exploratory study using informed scholarly opinion. J Small Bus Entrepreneur. 1996;13(3):29-56. doi:10.1080/ 08276331.1996.10600528

40. Wen ZL, Ye BJ. Analyses of mediating effects: the development of methods and models. Adv Psychol Sci. 2014;22(5):731-745. doi:10.3724/SP.J.1042.2014.00731

41. Bocker KBE, Baas JMP, Kenemans JL, Verbaten MN. Stimuluspreceding negativity induced by fear: a manifestation of affective anticipation. Int J Psychophysiol. 2001;43(1):77-90. doi:10.1016/ S0167-8760(01)00180-5

42. Grupe DW, Nitschke JB. Uncertainty and anticipation in anxiety: an integrated neurobiological and psychological perspective. Nat Rev Neurosci. 2013;14(7):488-501. doi:10.1038/nrn3524

43. Carlson JM, Greenberg T, Rubin D, Mujica-Parodi LR. Feeling anxious: anticipatory amygdalo-insular response predicts the feeling of anxious anticipation. Soc Cogn Affect Neurosci. 2011;6(1):74-81. doi: $10.1093 /$ scan/nsq017

44. Su XH, Chen JY, Zhang SJ, et al. Entrepreneurship for money or happiness? An exploring research of entrepreneurial motives, decision-making logic and entrepreneurial performance. Sci Sci Manag $S \&$ T. 2018;(2):116-129.

45. Kahneman D, Tversky A. Prospect theory: an analysis of decision under risk. Econometrica. 1979;47(2):263-291. doi:10.1017/ cbo9780511803475.003
Psychology Research and Behavior Management

\section{Publish your work in this journal}

Psychology Research and Behavior Management is an international, peer-reviewed, open access journal focusing on the science of psychology and its application in behavior management to develop improved outcomes in the clinical, educational, sports and business arenas. Specific topics covered in the journal include: Neuroscience, memory and decision making; Behavior modification and management; Clinical

\section{Dovepress}

applications; Business and sports performance management; Social and developmental studies; Animal studies. The manuscript management system is completely online and includes a very quick and fair peer-review system, which is all easy to use. Visit http://www. dovepress.com/testimonials.php to read real quotes from published authors. 